\title{
Localisation of ductile and brittle shear zones along the Szentlörinc-1 well in the Mecsekalja Zone using quartz microstructural and well-log data
}

\author{
Ágnes Skultéti ${ }^{1}$ Tivadar M. Tóth ${ }^{1}$
}

Received: 23 January 2015/ Accepted: 22 June 2015

(C) Akadémiai Kiadó 2015

\begin{abstract}
Quartz is among the most common minerals in the Earth's crust and is stable within a wide range of temperature and pressure conditions. As its microstructure is sensitive to different deformation mechanisms, quartz may present information about the structural evolution of many different rock types. The Szentlörinc-1 well with its drill cuttings brought to the surface from approximately $2 \mathrm{~km}$ depth provides an exclusive chance to investigate the shear zone beneath. The drill cutting collection includes only a few small rock grains, and more than $80 \%$ of the material consists of tiny $(<1 \mathrm{~mm})$ single quartz grains. In this study, three microstructurally extreme quartz grain types were separated during microscopic analysis: grains with undulose extinction $(U)$, grains with subgrains $(S)$, and grains with recrystallized grains $(R)$. Moreover, numerous microstructurally transitional grains were measured, which represent combinations of the above extremes. The characterisation of single quartz grain microstructures along the whole well enables identification and localisation of the ductile shear zones inside the crystalline complex. This information was combined with well-log data, which could provide information about the brittle deformation. Using these logs, brittle shear zones can be localised along the well. When comparing depths and extensions of the deformed horizons, a coincidence of the brittle and ductile zones becomes clear. This behaviour may suggest two different evolution schemes: it could be caused by primarily evolved softened regions, or it could be described by a detachment fault model.
\end{abstract}

Keywords Drill cuttings - Quartz $\cdot$ Microstructure $\cdot$ Well-log data $\cdot$ Shear zone localisation · Brittle and ductile shear zones

Ágnes Skultéti

skulteti.agi@gmail.com

Tivadar M. Tóth

mtoth@geo.u-szeged.hu

1 Department of Mineralogy Geochemistry and Petrology, University of Szeged, Szeged, Hungary 


\section{Introduction}

In several places, because of their intensive deformation, shear zones behave as excellent fractured fluid (hydrocarbon or geothermal) reservoirs. Therefore, the petrographic and structural characterisation of shear zone formations is of basic importance. The investigation of shear zone rocks is usually possible only in surface outcrops and, in cases of covered hard rock bodies, using drill core specimens, which provide only rather diffuse information. Our samples represent a newly bored geothermal well located inside the Mecsekalja shear zone, in the South Transdanubian region of Hungary (Fig. 1a). There was no bore core recovery in the Szentlörinc-1 well, and drill cuttings were brought to the surface from approximately $2 \mathrm{~km}$ depth, providing an exclusive chance to investigate the material of the shear zones beneath. The drill cutting collection includes only a few small rock fragments unsuitable for traditional petrographic and structural evaluation; more than $80 \%$ of the material consists of tiny $(<1 \mathrm{~mm})$ pieces of single quartz.

Quartz is present in the Earth's crust as a common and resistant mineral, and is stable across a rather wide range of temperature and pressure conditions. Its microstructure is nevertheless very sensitive to stress and, at various $\mathrm{P}-\mathrm{T}$ conditions quartz deforms by different deformation mechanisms resulting in grains with various microstructures. As a consequence quartz may provide valuable information regarding the structural evolution of numerous distinct rock types (Hirth and Tullis 1992; Stipp et al. 2002; Vernon 2004; Passchier and Trouw 2005; Halfpenny et al. 2012). During the deformation of quartz aggregates dislocation creep is an important mechanism defined by different dynamic recrystallization mechanisms (Hirth and Tullis 1992; Tullis et al. 2000). Dynamic recrystallization can occur in various forms depending on temperature and strain rate. These are bulging (Regime 1), subgrain rotation (Regime 2) and grain-boundary migration (Regime 3), with increasing temperature and decreasing strain rate (Hirth and Tullis 1992). The bulging recrystallization (BLG) (Hirth and Tullis 1992) takes place at low temperatures $\left(<300-400{ }^{\circ} \mathrm{C}\right.$ for quartz) (Passchier and Trouw 2005) and is characterized by deformed parent grains with a high dislocation concentration and undulose extinction (Halfpenny et al. 2012). Subgrain rotation recrystallization (SGR) occurs at higher temperatures (Hirth and Tullis 1992) (400-500 ${ }^{\circ} \mathrm{C}$ for quartz) (Passchier and Trouw 2005) and is characterized by ductility deformed, elongated and ribbon-shaped parent grains with many subgrains. As a result of this process the remains of old grains are commonly surrounded by groups of recrystallized grains (a feature known as a core-and-mantle structure in Gifkins 1976; White 1976; Shigematsu 1999) or may be completely replaced by recrystallized material (Hirth and Tullis 1992; Stipp et al. 2002). High temperature grain-boundary migration recrystallization (GBM) (Hirth and Tullis 1992) (500 to $<700{ }^{\circ} \mathrm{C}$ for quartz) is characterized by grains with new, lobate grain boundaries (Vernon 2004; Passchier and Trouw 2005).

In the previous phase of the recent research during the microscopic analysis of quartz grains, three microstructurally different end-member quartz grain types were distinguished from the subsurface shear zone in study: grains with undulose extinction (undulatory: $U$ ), grains with subgrains (subgrain: $S$ ), and grains with recrystallized grains (recrystallized: $R$ ). Moreover, several microstructurally transitional grains were identified, which represent combinations of the above end-members (Skultéti et al. 2014). The $U$ type quartz grains were formed by the bulging recrystallization mechanism (BLG) (Hirth and Tullis 1992), while the $S$ and $R$ type quartz grains most likely developed by subgrain rotation recrystallization (SGR) (Hirth and Tullis 1992) under different physical conditions (SGR I, SGR II) (Skultéti et al. 2014). In accordance with this phenomenon, the three end-member 

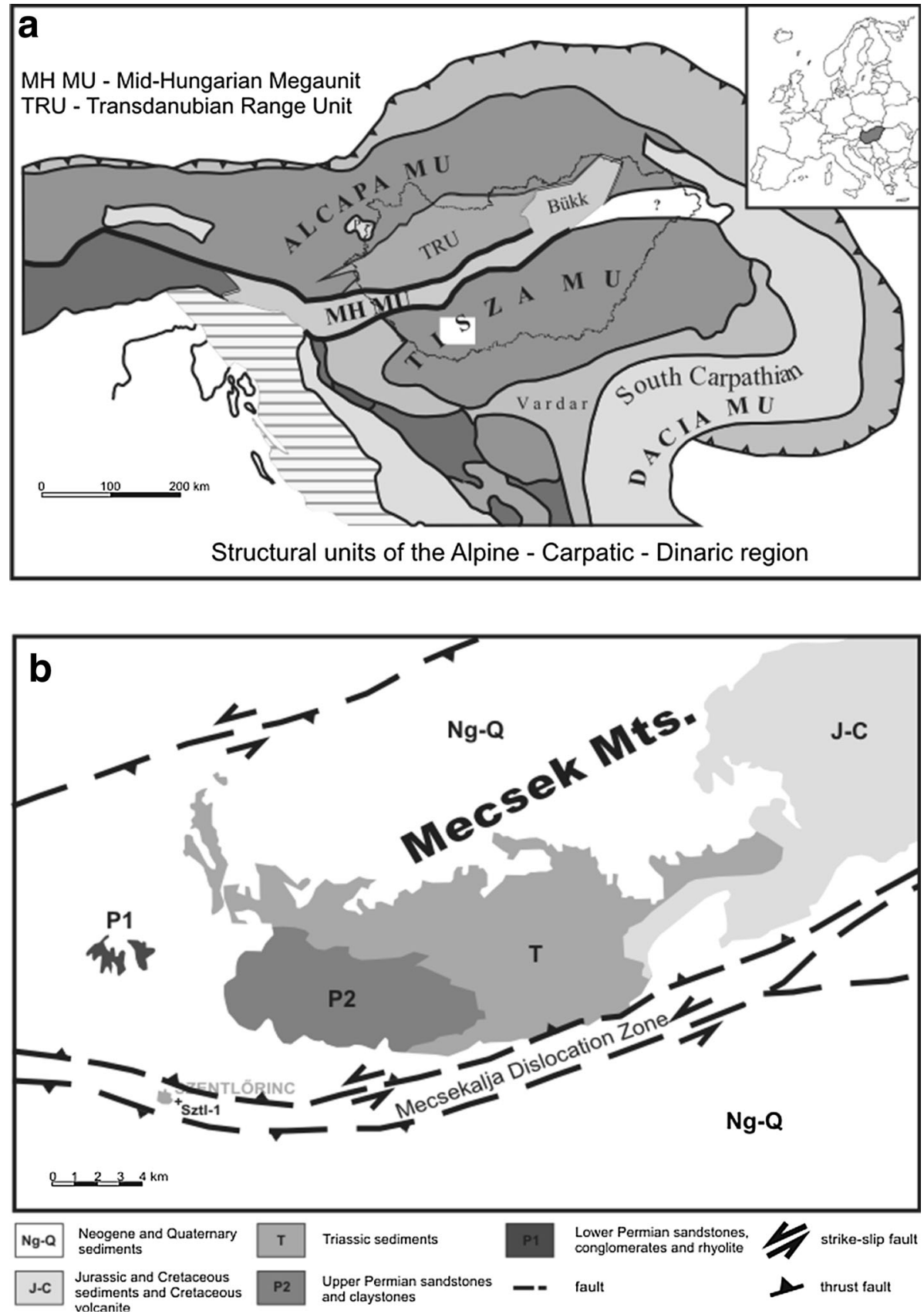

Fig. 1 a Location of the study area (white square) inside of the Pannonian Basin (based on Haas et al. 2010). b The Mecsekalja Zone with the studied Szentlörinc-1(Sztl-1) well (based on Konrád et al. 2010)

microstructural types formed by different deformation mechanisms represent diverse conditions with increasing temperature and/or decreasing strain rates from $U$ toward $R$ type (Skultéti et al. 2014). 
The primary aim of our study is to identify and locate the ductile shear zones inside the Mecsekalja shear zone along the Szentlörinc-1 well by characterising deformation mechanisms in a large set of single quartz chips at various depths. Afterwards, the brittle shear zones are determined using a wide set of well-logs and are compared to the depths of the ductile zones. Thus, the final aim is the reconstruction of the structure and deformation history of the fractured geothermal reservoir.

\section{Geological settings}

The Pannonian Basin was formed as a result of a complicated extension process during the Miocene (Tari et al. 1992). Its pre-Neogene, basically crystalline basement consists of crustal blocks of diverse origins and complex structural evolutions. The Alcapa and TiszaDacia Blocks are the main structural units in the basement of the Pannonian Basin, which were juxtaposed only in the Neogene (Fig. 1a).

In the Tisza-Dacia block, the structural evolution of the crystalline basement started during the Variscan orogeny (Árkai et al. 1985; Szederkényi 1984, 1996; Lelkes-Felvári and Frank 2006). The Variscan tectonic events were followed by a pervasive extension in the Jurassic (Csontos et al. 1992; Haas and Péró 2004) and then the nappe formation in the Cretaceous (Tari et al. 1999; Haas and Péró 2004). As a result of the complex basin subsidence in the Neogene (Bergerat 1989; Tari et al. 1992; Horváth and Cloetingh 1996; Csontos and Nagymarosy 1998), more kilometre deep sub-basins (Békés Basin, Makó Trough) and metamorphic basement highs (Tari et al. 1992, 1999; Zachar and M Tóth 2004, Schubert and M Tóth 2001; M Tóth et al. 2000; M Tóth and Zachar 2006) covered with several $\mathrm{km}$ thick sediment were formed. The basement formations deformed intensively during the Neogene subsidence. As a result of the complex tectonic evolution, the crystalline basement is made up from blocks with various metamorphic and structural evolutions (M Tóth et al. 2000; Schubert and M Tóth 2001).

The Mecsekalja zone is a $1.5 \mathrm{~km}$ wide tectonic zone inside of the Tisza-Dacia block; an active transcurrent zone since the Permian (Szederkényi 1977, 1979). In this dislocation belt (Fig. 1b), formations with various lithologies and in most parts intensively mylonitised metamorphic rocks were outcropped. The gneiss, quartzphyllite, crystalline limestone, serpentinite and amphibolite that fill out the Mecsekalja Zone belong to the Ófalu Group lithostratigraphically.

The oldest pre-Variscan and Variscan (Balla et al. 2009) events of the research area were the magmatic formation of the protolith (granite) and early regional metamorphism of the Studervölgy Gneiss. The rocks of the Ófalu Group were assembled by intensive tectonic movements into a new, larger coherent geological unit during the Early Carboniferous orogenic phase of the Variscian tectogenesis. Thus the following late Variscan tectonometamorphic events uniformly affected the newly formed geological and tectonic unit. During the principal post intrusive metamorphic event of the tectonometamorphic evolution of the Mecsekalja Zone, the rocks of the Ófalu Group uniformly suffered hightemperature greenschist facies $\left(>350-400{ }^{\circ} \mathrm{C}\right.$ ) regional metamorphism (Balla et al. 2009).

Based on geophysical data (Thorbergsdottir et al. 2010), it can be assumed that the studied Szentlörinc-1 well penetrated the deep sections of the Mecsekalja zone. The lithologies revealed by the well are Cenozoic, Mesozoic and Paleozoic aged. The Cenozoic, Miocene and Eocene formations are predominantly clastic sediments and sedimentary rocks. The Mesozoic includes limestone with clay intercalations, while the Paleozoic 
section consists of metamorphic rocks, mainly gneiss and mica-schist (Thorbergsdottir et al. 2010); the crystalline basement was penetrated by the well at $1330 \mathrm{~m}$ depth. Analyses of the samples from the basement enable the recognition of the subsurface formations of the Mecsekalja zone.

\section{Samples}

The investigated samples represent the Szentlörinc-1 (Sztl-1) deep drilling, the base of which reached a depth of $1820 \mathrm{~m}$. The well penetrated rocks of the Mecsekalja shear zone. Drill cuttings were taken every $5 \mathrm{~m}$ in the 1600-1820 $\mathrm{m}$ interval. The drill cuttings take the form of mm-size debris, constituted by single mineral and rock pieces in an 80:20 ratio, for the most part dominated by single quartz grains. The analysed samples were mainly individual quartz grains and quartz grain fragments. In this part of the research, the available quartz grains were examined every $25 \mathrm{~m}$, and analysis was performed every $5 \mathrm{~m}$ in the possible fractured zones defined by well-log interpretation.

\section{Methods}

\subsection{Microstructural analysis}

The microscopic analysis of the 17 normal thin sections, made from samples representing different depth intervals along the well (1600-1820 m), was performed using an Olympus BX-41 polarisation microscope using magnification of $\times 10$ and $\times 40$ objectives. Within the confines of microstructural analyses, the quartz grains of the available drill cutting samples were analysed every $25 \mathrm{~m}(1600,1625,1650,1675,1700,1725,1750,1775,1800$, $1820 \mathrm{~m}$ ), and in the possible fractured zones, the 1605, 1610, 1615, $1620 \mathrm{~m}$ and 1755 , $1760,1765 \mathrm{~m}$ samples were also studied. During the microscopic analysis, 100 pieces of randomly selected (JMicroVision: point counting method) quartz grains were microstructurally examined in every sample. The ratio of the microstructurally different quartz grains was analysed in the case of every depth interval.

The microstructural types identified during the examination were as follows (Fig. 2). End-member quartz grain types: grains with undulatory extinction $(U)$, grains with subgrains $(S)$ and grains with recrystallized grains $(R)$; microstructurally transitional quartz grain types: heterogeneous grains in which $U$ and $S$ type domains were observed in an approximately equal ratio $(U \approx S)$, grains in which $U$ type grains were dominant $(U>S)$, grains in which $S$ type grains were dominant $(S>U)$, transitional grains in which $S$ and $R$ type domains were observed in an approximately equal ratio $(S \approx R)$, grains in which $S$ type domains predominated $(S>R)$, and grains in which $R$ type grains predominated $(R>S)$. Moreover, there are such grains in which all of the three microstructural types appear in grains $(U-S-R)$. During the analysis of every measured sample (100 quartz grains), the proportion of the microstructurally different quartz grains was determined as a percentage $(\%)$.

The resulting data were plotted on special triangle diagrams (Fig. 3) every $25 \mathrm{~m}$ in depth, along the studied well section (1600-1820 m). At certain peak points of the diagram, the three extreme quartz grain types were represented. The cells between these three $(U, S, R)$ vertices and the central small triangle represented the microstructurally 

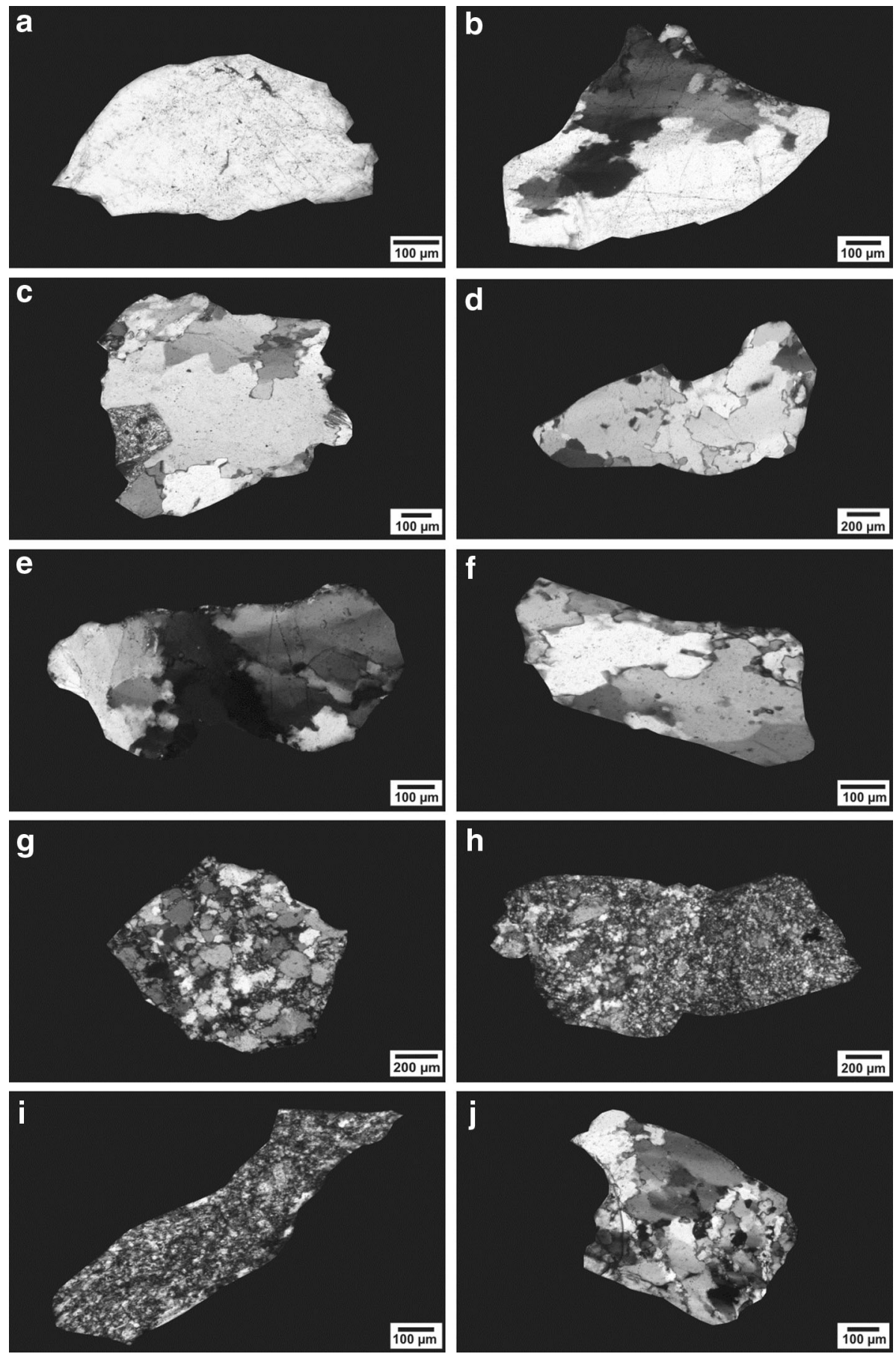

Fig. 2 Microstructural types of quartz in the studied samples a $U$ (microstructural class with undulatory extinction), b $\mathrm{U}>\mathrm{S}$, c $U \approx S$, d $S>U$, e $\mathrm{S}$ (microstructural class with subgrains), f $S>R, \mathbf{g} S \approx R$, h $R>S$, i $R$ (microstructural class with recrystallized grains), $\mathbf{j} U-S-R$ 
Fig. 3 Shape of the $U-S-$ $R$ triangle diagram. In certain peak points of the diagram, the three extreme quartz grain types are represented: grains with undulatory extinction $(U)$, grains with subgrains $(S)$ and grains with recrystallized grains $(R)$, subgrains. The cells between these three peak points and the central small triangle represent microstructurally transitional quartz grains

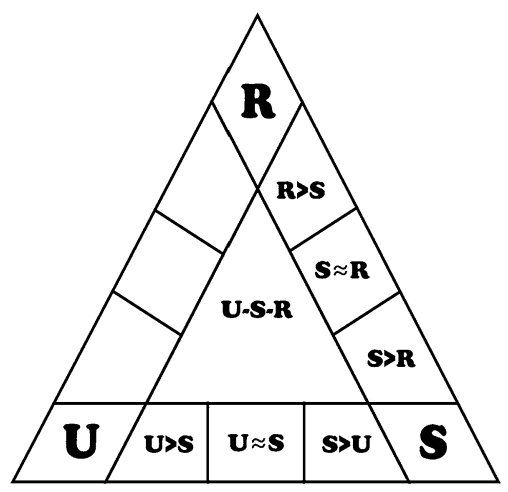

transitional quartz grains. On these special triangle diagrams, the percentile of the microstructurally different quartz grain types was marked by filling with various grey levels $(0 \%=$ white, $60 \%=$ black $)$.

\subsection{Well-log data analysis}

The aim of the well-log analysis was to determine the position of the intensively deformed brittle shear zones inside of the metamorphic section (1370-1820 m) of the studied well.

From the analysed Szentlörinc-1 deep drilling (Thorbergsdottir et al. 2010), coarse geophysical data every $10 \mathrm{~cm}$ and analogous well-logs are available for the whole drilling (2-1822 $\mathrm{m})$. During the assimilation of the coarse geophysical data, the corresponding well-logs were first sorted. Within the confines of separation, the porosity logs (density log) were sorted to determine those that could be used to locate the fractured, permeable zones (gamma, resistivity, spontaneous potential and calliper log). Then, the data of the selected well-logs were restricted to those intervals from which drill cutting samples are available. Thus, in the following, the data were analysed from 1600 to $1820 \mathrm{~m}$.

\subsubsection{Analysed well-logs}

The density log (long $35 \mathrm{~cm}$ detector distances) (DEL) is a porosity log that measures the formation's bulk density, including solid matrix and the fluid enclosed in the pores (Rider 1996). The formation bulk density is a function of the matrix density, porosity and density of the fluid in the pores. During the density measurement, a radioactive source emits gamma rays into the formation (Schlumberger Limited 1989), where they collide with electrons. The collisions result in a loss of energy from the gamma ray particle. The amount of scattered gamma rays reaching the detector is proportional to the electron density of the formation (Asquith and Gibson 1982; Schlumberger Limited 1989). In most rock types, the electron density is related to the formation's true bulk density (Tittman and Wahl 1965), and the bulk density is a function of porosity (Asquith and Gibson 1982; Schlumberger Limited 1989). Comparing the density log with gamma and calliper logs enables the determination of fractured zones (Rider 1996).

The gamma ray log (GR) is a lithology log, which measures the natural radioactivity of the formation. The natural radioactivity of the formations derives from ${ }^{40} \mathrm{~K}$, ${ }^{238} \mathrm{U},{ }^{232} \mathrm{Th}$ and their daughter elements (Asquith and Gibson 1982; Rider 1996). In the 
case of non-radioactive formations, the potassium content mostly relates to clay minerals and K-feldspar (Schlumberger Limited 1989). The geological significance of radioactivity lies in knowing the distribution of these three elements in the rocks. Most rocks are radioactive to some degree, igneous and metamorphic rocks more so than sediments. The gamma ray $\log$ often is used to determine clayey rock zones (Rider 1996).

The resistivity $\log$ (160 $\mathrm{cm}$ electrode distances) (R160) displays the formation's resistance to the passage of an electric current. Electricity can pass through a formation only because of the conductive fluid it contains. Dry rocks are good electrical insulators (Schlumberger Limited 1989), although perfectly dry rocks are very rarely encountered in nature. Therefore, the subsurface formations have measurable resistivity because of the resistivity of the fluid in their pores or absorbed on their interstitial clay (Asquith and Gibson 1982; Schlumberger Limited 1989). The resistivity of the formation depends on the resistivity and amount of formation water and the pore structure geometry (Schlumberger Limited 1989). The resistivity of the formation can be measured by either sending current into the formation and measuring the ease of the electrical flow through it or by inducing an electric current into the formation and measuring how large it is (Schlumberger Limited 1989). The resistivity $\log$ can be used to indicate permeable zones and determine resistivity porosity (Asquith and Gibson 1982).

The spontaneous potential log (SP) measures the direct current voltage differences between an electrode in the borehole and a reference electrode at the surface (Asquith and Gibson 1982; Schlumberger Limited 1989; Rider 1996). They originate from the electrical disequilibrium created by connecting formations vertically (in the electrical sense) when in nature they are isolated (Rider 1996). Three factors are necessary to provoke an SP current: (1) a conductive fluid in the borehole, (2) a porous and permeable bed surrounded with an impermeable formation and (3) a difference in salinity or in pressure between the borehole fluid and the formation fluid (Rider 1996). If the bed is not permeable, the ions cannot move; accordingly, flow does not occur and there is no potential change, so there is no spontaneous potential (Schlumberger Limited 1989). SP currents are created when two solutions of different salinity concentrations are in contact by two principal electrochemical effects: diffusion potential and shale potential (Asquith and Gibson 1982; Schlumberger Limited 1989; Rider 1996). The SP log displays not absolute values but the deflection of the curve from zero into positive or negative directions. The zero point is defined on thick shale intervals where the SP does not move and is called the shale base line. All values are related to this line (Rider 1996). The spontaneous potential $\log$ can be used to characterise the permeability of formations. Permeable zones are indicated where SP deflection appears from the shale baseline. However, the amount of deflection does not indicate the amount of permeability: a very slightly permeable bed will give the same value as a permeable bed (Asquith and Gibson 1982; Schlumberger Limited 1989; Rider 1996).

The calliper log (CL) displays the borehole diameter with the depth, where diameter is defined by the bit size. The simple calliper log records the vertical profile of the borehole diameter, while the more complex borehole geometry tools provide accurate information about the borehole shape, orientation and volume. The deflection from the bit size can be caused by various factors but is often due to lithological reasons and indicates the instability of the borehole wall. The calliper log can be used to dissociate the fractured zones, in which the borehole is enlarged because the rocks are mechanically less stabile (Schlumberger Limited 1989). 


\subsubsection{Interpretation of well-logs: discriminant function analysis}

Each well-log provides some information about the depth position of the fractured zones through increased porosity and permeability as well as enhanced clay mineral content in the formation along the studied well section. However, a simultaneous application of the analysed well-logs could provide a more reliable and general idea about the location of the fractured zones (Molnár et al. 2014a).

During the analysis of the combination of the various well-logs, the well-log was selected first in which the highly fractured and the fresh rock zones along the well were most markedly distinct. Based on this choice, inside of the well, ca. $10 \mathrm{~m}$ long fractured and fresh rock zones were selected, and the coarse geophysical data representing these sections were selected from all of the analysed well-logs.

Next, discriminant function analysis was performed for the geophysical data that represent the fractured and fresh rock zones along the well, respectively. In this way, the linear combination of the well-logs can be computed to best discriminate the fractured and fresh rock zones. The final aim of the statistical analysis was to use this separation function for the whole studied section. The discriminant function analysis was performed using IBM SPSS Statistics Version 20.0.

\section{Results}

\subsection{Microstructural results}

The proportion of quartz grains of different microstructural classes in drill cuttings that represent consecutive depth intervals $(1600-1820 \mathrm{~m})$ are summarised in Table 1 and Fig. 4. In the studied drill cutting samples, beside the quartz grains, rock fragments are also present that consist of muscovite, biotite, K-feldspar and plagioclase. Inside the upper part of the analysed well section ca. 1600-1750 m, muscovite and K-feldspar are dominant phases of the rock fragments, while further downward $(1775-1820 \mathrm{~m})$, the amount of biotite and plagioclase increases.

\subsection{Geophysical results}

In this study, the resistivity, density, gamma, spontaneous potential and calliper logs were interpreted (Fig. 5).

The resistivity log (Fig. 5a) displays a decrease in resistivity values ca. 1580-1605 m. After that, a significant resistivity increase could be observed from $1605 \mathrm{~m}$ down to ca. $1615 \mathrm{~m}$, and the resistivity falls markedly between 1615 and $1635 \mathrm{~m}$ again. Between 1750 and $1765 \mathrm{~m}$, the resistivity log similarly displays a significant decrease. Moreover, along the well-log, smaller, less significant resistivity drops can be observed (at 1650, 1680, 1705 and $1738 \mathrm{~m})$.

The density $\log$ (Fig. 5b) displays a significant density increase between 1605 and $1615 \mathrm{~m}$, which is followed by a density reduction between 1615 and $1635 \mathrm{~m}$. Between 1750 and $1765 \mathrm{~m}$, a density decrease could be observed. In addition, smaller density falls could be determined at 1650,1680 and $1705 \mathrm{~m}$.

On the gamma log (Fig. 5c), one could observe that the gamma values are generally higher $(>20 \mu \mathrm{R} / \mathrm{h})$ between 1600 and $1710 \mathrm{~m}$, while they tend to be smaller between 1710 
Table 1 Amount of microstructurally diverse quartz grain types at different depth intervals along the Sztl-1 well

\begin{tabular}{|c|c|c|c|c|c|c|c|c|c|c|}
\hline \multirow[t]{2}{*}{ Depth (m) } & \multicolumn{10}{|c|}{ Quartz grain types (\%) } \\
\hline & $\mathrm{U}$ & $\mathrm{S}$ & $\mathrm{R}$ & $\mathrm{S}=\mathrm{R}$ & $S>R$ & $\mathrm{R}>\mathrm{S}$ & $\mathrm{U}=\mathrm{S}$ & $\mathrm{U}>\mathrm{S}$ & $\mathrm{S}>\mathrm{U}$ & $\begin{array}{l}\text { U-S- } \\
\text { R }\end{array}$ \\
\hline 1600 & 4 & 6 & 1 & 46 & 23 & 16 & 1 & 2 & 0 & 1 \\
\hline 1605 & 2 & 11 & 5 & 22 & 38 & 21 & 0 & 0 & 1 & 0 \\
\hline 1610 & 1 & 5 & 3 & 47 & 23 & 15 & 1 & 2 & 0 & 3 \\
\hline 1615 & 0 & 1 & 2 & 30 & 12 & 54 & 0 & 0 & 0 & 0 \\
\hline 1620 & 1 & 2 & 0 & 43 & 18 & 36 & 0 & 0 & 0 & 0 \\
\hline 1625 & 1 & 3 & 0 & 35 & 21 & 40 & 0 & 0 & 0 & 0 \\
\hline 1650 & 0 & 1 & 0 & 44 & 44 & 11 & 0 & 0 & 0 & 0 \\
\hline 1675 & 1 & 6 & 1 & 38 & 31 & 23 & 0 & 0 & 0 & 0 \\
\hline 1700 & 2 & 4 & 0 & 37 & 30 & 26 & 0 & 1 & 0 & 0 \\
\hline 1725 & 3 & 3 & 0 & 35 & 28 & 30 & 1 & 0 & 0 & 0 \\
\hline 1750 & 0 & 0 & 2 & 44 & 13 & 41 & 0 & 0 & 0 & 0 \\
\hline 1755 & 0 & 2 & 0 & 68 & 20 & 7 & 0 & 0 & 0 & 3 \\
\hline 1760 & 0 & 1 & 0 & 70 & 20 & 8 & 0 & 0 & 0 & 1 \\
\hline 1765 & 0 & 3 & 0 & 65 & 24 & 7 & 0 & 0 & 0 & 1 \\
\hline 1775 & 0 & 1 & 1 & 57 & 35 & 7 & 0 & 0 & 0 & 0 \\
\hline 1800 & 0 & 0 & 0 & 51 & 45 & 4 & 0 & 0 & 0 & 0 \\
\hline 1820 & 5 & 8 & 0 & 31 & 34 & 13 & 1 & 2 & 0 & 6 \\
\hline
\end{tabular}

and $1820 \mathrm{~m}(<20 \mu \mathrm{R} / \mathrm{h})$. Thus, along the well-log, zones with higher and lower gamma values could be separated. Inside of the zone between 1600 and $1710 \mathrm{~m}$, from 1605 to $1610 \mathrm{~m}$, significantly higher gamma values are typical than in the sections between 1600 and $1605 \mathrm{~m}$ and $1610-1615 \mathrm{~m}$.

The spontaneous potential log (Fig. 5d) displays a significant potential reduction between 1615 and 1640 and $1750-1770 \mathrm{~m}$.

The calliper $\log$ (Fig. 5e) records an appreciable increase in the borehole diameter at $1680 \mathrm{~m}$ and between 1750 and $1765 \mathrm{~m}$, while less significant borehole enlargement could be observed at approximately 1625, 1650 and $1705 \mathrm{~m}$.

\section{Discussion}

\subsection{Ductile deformation}

The distribution of the strain inside a shear zone is not homogeneous in most cases; instead, it tends to be localised into planar horizons. Shear zones and faults develop along these shear localisation structures, and both involve displacement parallel to the walls (Passchier and Trouw 2005; Fossen 2010). The shear zones are tabular zones in which strain is notably higher than in the surrounding rock body (Fossen 2010). The shear zones can be ductile, brittle (fault) or transitional brittle-ductile structures. In the case of ductile shear zones, the central zone with a higher deformation grade is enveloped by lower 


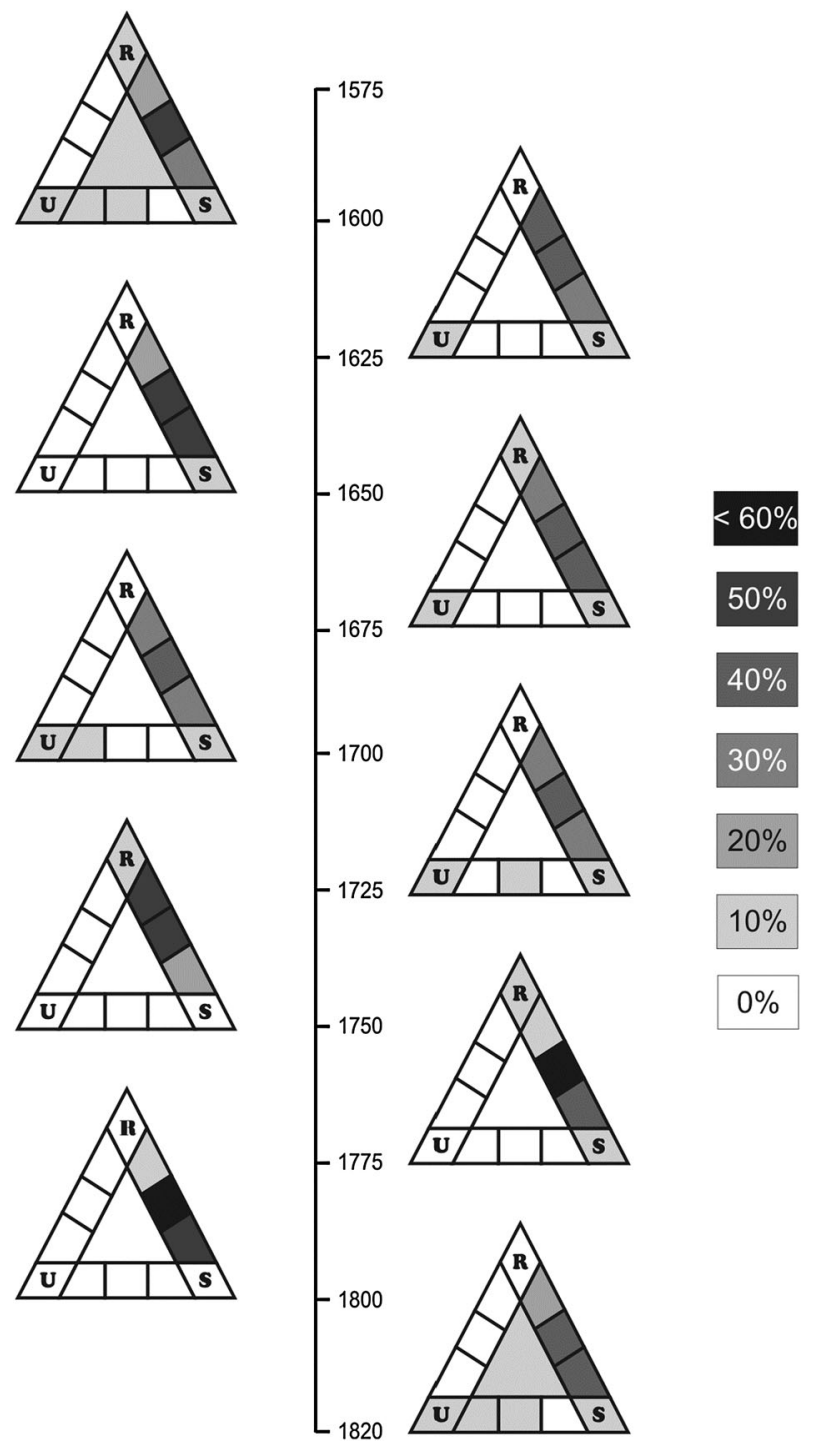

Fig. 4 Proportion $(\%)$ of the microstructurally different quartz grain types along the studied well with depth delineated on $U-S-R$ triangle diagrams

deformation grade belts. Thus, the intensity of deformation decreases from the middle of the shear zone outward (Wibberley et al. 2008).

Quartz is a stable mineral under wide P-T conditions; it nevertheless deforms in different ways at diverse $\mathrm{P}, \mathrm{T}$ and strain rates following diverse deformation mechanisms, resulting in grains with various microstructures (Hirth and Tullis 1992; Vernon 2004; Passchier and Trouw 2005). As a consequence, in quartz-bearing rocks, each quartz grain may provide valuable information about the deformation history of the rock body itself. 


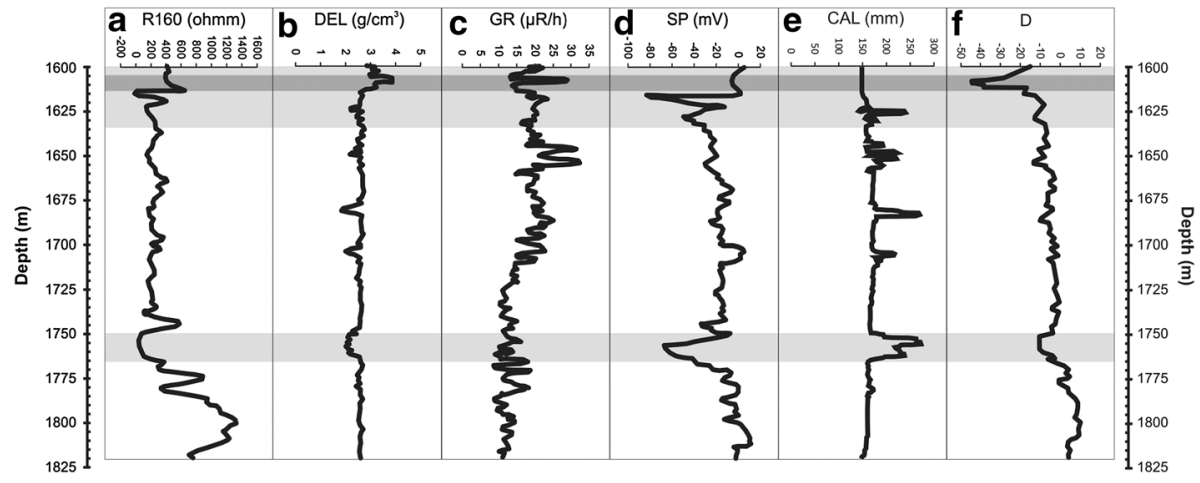

Fig. 5 Well-logs of the Sztl-1 well (1600-1820 m) using brittle shear zone localisation: a resistivity (R160), b density (DEL), c gamma ray (GR), d spontaneous potential (SP), e calliper log (CAL), f composite $\log (\mathrm{D})$ computed by discriminant function analysis. The grey bands display the potential brittle shear zones

Fig. 6 Proportion of the $R>S$ (microstructurally transitional quartz grain types in which $R$ type grains are dominant) and $R$ type (extreme quartz grain types with recrystallized grains) quartz grains along the well (1600-1820 m) in relation to depth. The proportion of the $\mathrm{R}$ type grains was represented in tenfold magnification because of the better visibility

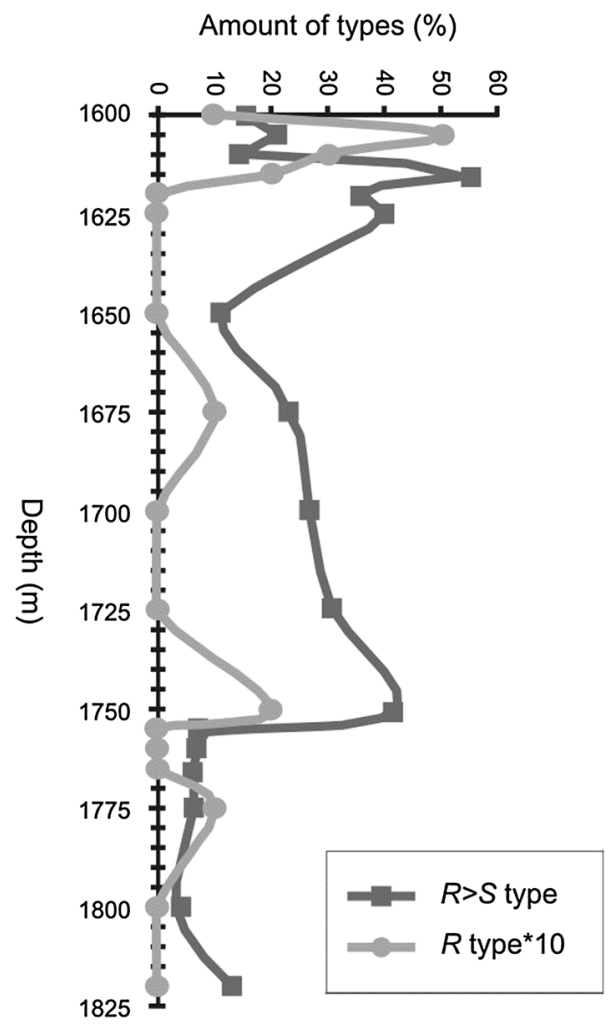

The proportion of recrystallized $(R)$ and dominantly recrystallized $(R>S)$ quartz grains displays two maxima inside of the studied well section between 1610 and $1635 \mathrm{~m}$ and 1750-1765 m (Fig. 6). Away from these depth intervals, the amount of recrystallized grains gradually decreases, while $U$ and $S$ type quartz grains and domains become dominant. 
The three microstructural quartz classes $(U, S, R)$ develop due to different deformation mechanisms (BLG, SGR I, SGR II) and thus represent a range of changing deformation conditions (Hirth and Tullis 1992; Passchier and Trouw 2005; Skultéti et al. 2014). During the deformation of minerals, temperature is an important factor. However, there are also other considerations such as strain rate, differential stress and the presence of water in the lattice and along grain boundaries, which also have relevant contributions to quartz deformation behaviour. In most cases, under high-temperature conditions, the recovery and recrystallization processes are promoted. At high strain rates, the role of crystal distortion increases, and due to the increased differential stress, more slip systems become active because of the reduction of the critical resolved shear stress of other slip systems (Hirth and Tullis 1992; Passchier and Trouw 2005). Thus, from $U$ to $R$ type, a continuous change of deformation conditions associated with increasing temperature $\left(\Delta \mathrm{T}=250-500{ }^{\circ} \mathrm{C}\right)$ or with decreasing strain rate can be assumed.

There is no reason to presume a significant change in metamorphic temperature within a few tens of metres long section of the rock column. However, in shear zones with increasing strain, the quartz grains display a sequence of transient microstructures, indicating diverse deformation mechanisms. Thus, it can be assumed that toward the central region of a shear zone, simultaneously with increasing strain, the BLG, SGR I and SGR II dynamic recrystallization processes become dominantly active. Therefore, with increasing strain, the amount of recrystallized quartz grains ( $R$ type) should increase (Lloyd et al. 1992; Dell'Angelo and Tullis 1996; Menegon et al. 2008). Thus it is probable that in the studied well, the $R$ type quartz grains mark the most intensively deformed zones, while the $U$ and $S$ type grains denote the zones with weaker deformation. The intensively deformed core section of a ductile shear zone is usually dominated by $R$ type grains, while further away the less deformed zones are denoted by increased frequency of $U$ and $S$ type quartz grains. Using this theoretical consideration, on the basis of our samples, ductile shear zones could be localised in two sections, one between 1610 and $1635 \mathrm{~m}$ and another at 1750-1765 $\mathrm{m}$ along the studied well section. An abrupt change in the mineralogical composition of the rock fragments (from muscovite and K-feldspar dominated to biotite and plagioclase dominated) also occurs at approximately $1750 \mathrm{~m}$ depth.

\subsection{Brittle deformation}

Brittle shear zones usually consist of a central slip surface or core, developed by intense shearing, and a surrounding volume of rock (damage zone) affected by less intense brittle deformation (Fossen 2010; Wibberley et al. 2008). The fault core is frequently less permeable because of its high secondary clay mineral (fault gouge) content (Fossen 2010). As the gamma ray value is related to the clay content of the formation (Asquith and Gibson 1982; Schlumberger Limited 1989; Rider 1996), it can be assumed that a fault gouge zone is situated between 1605 and $1615 \mathrm{~m}$ and surrounded on both sides (between 1580 and $1605 \mathrm{~m}$ and $1615-1635 \mathrm{~m}$, respectively) by more permeable damage zones. In the studied well section between 1750 and $1765 \mathrm{~m}$, a highly fractured and more permeable zone can be observed. Moreover, at approximately 1650, 1680 and $1705 \mathrm{~m}$, local fractured rocks can also be identified.

To more precisely locate the most intensively fractured intervals along the well, discriminant function analysis was performed based on the digitised well-log data. For this purpose, data representing the two most different sections 1754-1765 (fractured) and 1789-1800 m (fresh) were compared first. The calculations resulted in a discriminant function $(\mathrm{F})$, 


$$
F=-5.52 \times D E L-0.22 \times G R+0.01 \times R 160+0.06 \times S P+11.75
$$

which describes the best linear combination of the geophysical parameters and separates the best the highly fractured and the fresh rock zones along the studied well. As a result, it could be established that the most important (large weights in the discriminant function) variable in separation is density, while gamma rays, resistivity and spontaneous potential have only minor roles. Based on the resulting $D$ composite well-log (Fig. 5f), two major fractured zones become clear between 1580 and $1605 \mathrm{~m}$ and between 1750 and $1765 \mathrm{~m}$, respectively.

On the basis of the available geophysical data, between 1580 and $1635 \mathrm{~m}$, one can assume the presence of an intensively deformed brittle shear zone with a well-developed argillaceous core zone (between 1605 and $1615 \mathrm{~m}$ ) enveloped by highly fractured damage zones on both sides. Moreover, at approximately 1650, 1680 and 1705, minor fractured zones could be assumed. During the seismic analysis of the study area in the environment of Sztl-1 well Tulinius et al. (2010) also identified a fault zone at the similar depth interval (1600-1700 m) of the crystalline basement.

The spontaneous potential log displays significant changes between 1615 and $1640 \mathrm{~m}$ and between 1750 and $1770 \mathrm{~m}$. This phenomenon can be caused by the changing electrochemical behaviour of drilling mud that has been modified by the mixing of borehole fluid with formation water originated from an outward source. These peaks on the $S P \log$ mark water inflow zones along the well, confirming the positions of the highly fractured, permeable horizons.

\subsection{Possible geodynamical interpretations}

When comparing the depths and extensions of the deformed horizons of the Szentlöric-1 well, a notable coincidence of ductile and brittle (presumably cataclasite, breccia zones) shear zones becomes clear (Fig. 7). This spatial appearance allows two different scenarios concerning structural evolution: they either formed due to the same tectonic episode or belong to different events.

In the continental lithosphere, the localisation of tectonic activity is influenced by many factors: beyond the temporal and spatial deviations in the thermal state of the lithosphere (Sonder and England 1986; England 1987), the presence of old faults and shear zones are also essential factors (Holdsworth et al. 2001). The formation of faults and shear zones is usually followed by a number of softening processes, which can cause substantial weakening both coincidentally with deformation and in the long-term. The generations of previous cohesionless fractures, grain refinement processes, general reaction softening, geometric and fabric softening and thermal perturbations in faults and shear zones lead to long-term weakening. Other processes, such as shear heating, increase in pore fluid pressure, transient fine-grained reaction products, transformational plasticity, variations in pore fluid chemistry and fluid-assisted diffusive mass transfer may cause transient weakening in faults and shear zones (Holdsworth et al. 1997).

Thus, if the firstly evolved ductile shear zones caused softened regions inside the crystalline mass, it could reactivate later in a brittle way due to a tectonic event independent of the early one. The early faults and shear zones in the continental crust operate as softened planes, so when the crust is experienced new stress field, those areas perform as preferred regions for reactivation (White et al. 1986). Holdsworth et al. (1997) defined the reactivation as the emplacement of geologically separable displacement episodes (intervals $>1 \mathrm{Ma}$ ) along the primarily formed structures. In the continental crust, the structural 
Fig. 7 Characterization of single

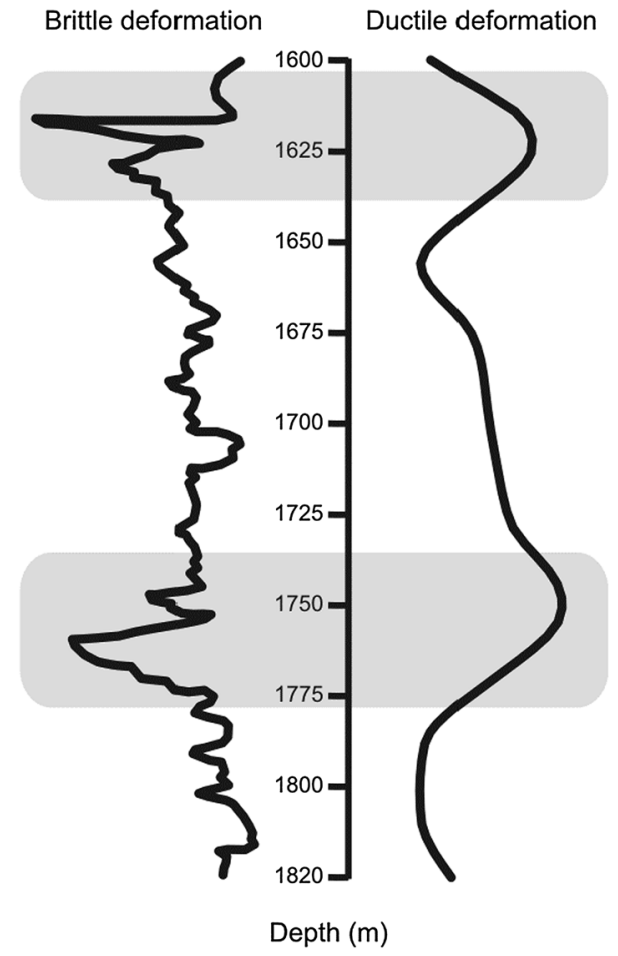
quartz grain microstructures along the whole Sztl-1 well enables localization of the ductile shear zones inside the crystalline complex, these zones coincide very well with the brittle horizons defined by well-log evaluation

reactivation is an essential procedure of the deformation. The long-lived weakening zones in the continental crust recurrently reactivate, and thus, the subsequent crustal strains may cause the formation of new regions of displacements (Hills 1956; Prucha 1992; Holdsworth et al. 1997). The stress in the continental crust is the particular cause of the reactivation, but it is also a function of the orientation of the fault-zone with respect to the imposed stress field, their capability to accommodate the resultant strains and the presence of rocks that form along faults (fault gouges, cataclasites, mylonites) (White et al. 1986). The repeated localisation of displacements along faults and shear zones over a very long time may lead to more intense weakening of these zones relative to the nearby crust (White et al. 1986; Holdsworth et al. 1997, 2001; Rutter et al. 2001).

The brittle reactivation of basement ductile shear zones during the early stages of continental rift evolution has been observed in many areas, such as the North Atlantic rift (Wilson 1966), the Rio Grande rift (Olsen et al. 1987), the East African rift (Fairhead and Binks 1991), and the West European rift (Michon et al. 2003) among many others. Provided that the ductile and brittle structures formed subsequently due to the same tectonic event, the deformed zones may represent a detachment fault. The detachment faults are long-term, low-angle normal faults with significant displacements and subregional-regional extent (Lister et al. 1986; Davis 1988; Lister and Davis 1989). These structures develop as the result of continental extension, when the middle and lower continental crust, deformed in a ductile way, is uplifted to the brittle upper crust. As a consequence, ductile and brittle deformations overlap along the same shear zones (Lister and Davis 1989). As the lower crust rocks are raised from the deeper level to the surface, they carry over a series of various metamorphic and deformational conditions that include a continuously reducing 
metamorphic grade (usually amphibolite down to sub-greenschist facies) and different ways of deformation with the decreasing depth (Lister and Davis 1989). Large-scale detachment faults usually divide crystalline blocks of significantly different metamorphic evolutions in the footwall (lower plate) and the hanging wall (upper plate) (Lister et al. 1986; Lister and Davis 1989). In the upper plate, the deformation processes occurred in a brittle way, but along the detachment fault, the shearing is primarily plastic. Detachment faults are often conjugate with lower plate mylonitic gneisses that form the metamorphic core complexes (Davis and Lister 1988; Lister and Davis 1989). These core complexes are developed during continental extension and are characterised by a core of intensely deformed metamorphic rocks. The core complexes are usually restricted by low-angle detachment faults that are narrow in the upper plate; therefore, the metamorphic lower plate rocks eventually arrive at the surface (Lister and Davis 1989).

The first mapping and defining of the metamorphic core complexes occurred in the Basin and Range region in Arizona and Nevada (Wernicke 1985; Davis and Lister 1988; Gans et al. 1989; Faulds and Geissman 1992; Piper et al. 2010). Comparable structures have since been found in numerous places such as the Cordillera of Western North America (Kerrich 1988; Lister and Davis 1989; Foster and Raza 2002), the Whipple Mountains, southeastern California (Davis 1988; Lister and Davis 1989; Stockli et al. 2006) and the Buckskin Mountains, western Arizona (Davis et al. 1979; Heidrick and Wilkins 1980; Brady 2002). Detachment faults and metamorphic core complexes are also well-known structures in the metamorphic basement of the Pannonian Basin, even close to the studied well (Tari et al. 1992; Posgay et al. 1996; Tari et al. 1999; M Tóth et al. 2000; Schubert and M Tóth 2001; Zachar and M Tóth 2004).

The present area of the Pannonian Basin complex underwent extensional conditions several times during its evolution in the last 300 Ma. Following the totally unknown exhumation phase of the Variscan orogeny, continental rifting occurred during the Jurassic, which was associated with the formation of the Magura-ocean (Haas and Péró 2004). Finally, during the Neogene, complex basin subsidence occurred (Bergerat 1989; Tari et al. 1992; Horváth and Cloetingh 1996; Csontos and Nagymarosy 1998), resulting in the formation of several kilometre deep sub-basins (Békés Basin, Makó Trough) and metamorphic basement highs among them. The explanation of reflection seismic profiles displays distinct mechanisms of upper crustal extension in the Pannonian basin (Tari et al. 1992). Underneath most parts of the basin, the amount of crustal extension is predicted to have been approximately 50-120 \% (Horváth et al. 1988). In the Pannonian Basin complex, there are subbasins with little extension (planar rotational normal faults) and with large extension (detachment fault faults and formation of metamorphic core complexes) (Tari et al. 1992). Based on seismic sections from the Pannonian basin as interpreted by Tari et al. (1999), characteristic lowangle dipping fault planes and intensively tilted middle Miocene strata could be observed, indicating significant extension (Wernicke and Burchfiel 1982).

Several boreholes reached the basement below Neogene sedimentary rocks at approximately $2 \mathrm{~km}$ depth. Petrological interpretation of the core material at numerous localities confirms the presence of low-angle faults, which separate blocks of different metamorphic evolutions inside the basement. In the Szeghalom Dome crystalline block, M Tóth et al. (2000) described different zones with significantly distinct metamorphic and structural evolution. By detailed microstructural evaluation of a single borehole, the adjacent rock types with different $\mathrm{P}-\mathrm{T}$ histories are separated by well-developed breccia zones of several tens of metres width (Molnár et al. 2014b). Molnár et al. (2014a) extended this detachment horizon using well-log data of numerous neighbouring wells, suggesting the presence of a low-angle fault zone. Based on the investigations of Nagy and M Tóth (2012), there are 
four basic lithologies in the Kiskunhalas-NE basement area. In the lithological column between the uppermost graphitic carbonate phyllite and the lowermost orthogneiss formations, there is $\sim 200{ }^{\circ} \mathrm{C}$ of peak metamorphic temperature deviation. It can be assumed that the two metamorphic blocks became juxtaposed along an extensional fault zone in the basement. Fiser-Nagy et al. (2014) described a series of south-dipping normal faultbounded blocks in this area, with shallow dipping mylonite/gneiss boundaries. These lowangle $\left(\sim 5^{\circ}\right)$ mylonitised zones refer to a detachment fault structure related to the formation of a metamorphic core complex. In the metamorphic block of the Görcsöny Ridge, the Baksa- 2 borehole revealed two distinct realms with significantly different $\mathrm{P}-\mathrm{T}$ histories of their metabasic rocks (M Tóth 2014). It can be assumed that the crystalline basement of the Görcsöny Ridge includes associated fragments of diverse origins. In the Pannonian Basin, detachment faults and metamorphic core complexes could be associated with the extension caused either by the Magura-ocean formation in the Jurassic (Csontos et al. 1992; Haas and Péró 2004) or the opening of the basin during the middle Miocene (Tari et al. 1992). Detailed age data on the single detachment faults has not been published yet.

To decide which of the two scenarios may be valid in case of the studied Szentlörinc-1 well, thermobarometric calculations below and above the shear horizons should be performed.

\section{Summary and conclusions}

The microstructure of available quartz grains may provide valuable information about the structural evolution of many different rock types. The microstructural analysis of the quartz grains enables the identification of various quartz grain types. The characterisation of single quartz grain microstructures using the above technique along the whole well enables localisation of the ductile shear zones inside of a crystalline complex even without available bore core information. In this study, the drill cutting samples of Szentlörinc-1 geothermal well (SW Hungary) were investigated. The ductile deformation data were originated from the microstructural analysis was completed with well-log data, which provide information about the brittle deformation. Using these logs, brittle shear zones (presumably cataclasite, breccia zones) can also be localised along the well.

When comparing depths and extensions of the deformed horizons, a coincidence of the brittle and ductile zones becomes clear. This behaviour may suggest two different evolution schemes. If the first evolved ductile shear zones formed softened regions inside of the crystalline mass, it could reactivate later in a brittle way due to a tectonic event independent of the early event. However, if these structures formed due to the same tectonic event, these zones may represent a detachment fault. Thus, to know which of these schemes is true in the case of our study area, information about the metamorphic evolution of the footwall and hanging wall formations is essential. This information can be determined using the chemical compositions of the available quartz grains based on the "Ti-in-quartz" thermometer (Wark and Watson 2006; Thomas et al. 2010; Huang and Audétat 2012; Kidder et al. 2013; Haertel et al. 2013). If the metamorphic grades of the footwall and hanging wall formations are nearequivalent, then the coincidence of the brittle and ductile shear zones could be caused by primarily evolved softened regions. If their metamorphic grades are significantly different, we have successfully identified a detachment fault, using only single quartz grains of drill cuttings. These measurements and calculations are, nevertheless, outside the scope of this paper. 
Acknowledgments We thank Mannvit Ltd. and László Ádám for providing the samples and the Geo-Log Ltd. and the PannErgy Plc. for geophysical data. This research was supported by TÁMOP-4.2.2.A-11/1/ KONV-2012-0047. English was corrected by American Journal Experts.

\section{References}

Árkai P, Nagy G, Dobosi G (1985) Polymetamorpic evolution of the South-Hungarian crystalline basement, Pannonian Basin: geothermometric and geobarometric data. Acta Geol Hung 28:165-190

Asquith GB, Gibson CR (1982) Basic well log analysis for geologists. The American Association of Petroleum Geologists, Tulsa

Balla Z, Császár G, Gulácsi Z, Gyalog L, Kaiser M, Király E, Koloszár L, Koroknai B, Magyari Á, Gy Maros, Marsi I, Molnár P, Rotárné Szalkai Á, Gy Tóth (2009) A Mórágyi-rög északkeleti részének földtana. Magyarország tájegységi térképsorozata. MÁFI, Budapest

Bergerat F (1989) From pull-apart to the rifting process: the formation of the Pannonian Basin. Tectonophysics 157:271-280

Brady RJ (2002) Very high slip rates on continental extensional faults: new evidence from (U-Th)/He thermochronometry of the Buckskin Mountains, Arizona. Earth Planet Sci Lett 197:95-104

Csontos L, Nagymarosy A (1998) The Mid-Hungarian line: the zone of repeated tectonic inversion. Tectonophysics 297:51-71

Csontos L, Nagymarosy A, Horváth F, Kovac M (1992) Tertiary evolution of the Intra-Carpathian area: a model. Tectonophysics 208:221-241

Davis GA (1988) Rapid upward transport of mid-crustal mylonitic gneisses in the footwall of a Miocene detachment fault, Whipple Mountains, southeastern California. Geol Rundsch 77(1):191-209

Davis GA, Lister GS (1988) Detachment faulting in continental extension: perspectives from the southwestern U.S. Cordillera. In: John Rodgers symposium volume 218. Geological Society of America Special Papers, pp 133-159

Davis GA, Anderson JL, Frost EG, Shackleford TJ (1979) Regional Miocene detachment faulting and early Tertiary (?) mylonitization, Whipple-Buckskin-Rawhide Mountains, southeastern California and western Arizona. In: Abott PL (ed) Geological excursions in the Southern California Area. San Diego State University Publications, San Diego, California, Dept Geol Sci, pp 74-108

Dell'Angelo LN, Tullis J (1996) Textural and mechanical evolution with progressive strain in experimentally deformed aplite. Tectonophysics 256:57-82

England PC (1987) Diffuse continental deformation; length scales, rates and metamorphic evolution. Philos Trans R Soc Lond 321:2-22

Fairhead JD, Binks RM (1991) Differential opening of the Central and South Atlantic Oceans and the opening of the West African rift system. Tectonophysics 187:191-203

Faulds JE, Geissman JW (1992) Implications of palaeomagnetic data on Miocene extension near a major accommodation zone in the Basin and Range Province. Tectonics 11:204-227

Fiser-Nagy Á, Varga-Tóth I, M Tóth T (2014) Lithology identification using open-hole well-log data in the metamorphic Kiskunhalas-NE hydrocarbon reservoir, South Hungary. Acta Geod Geophys 49:57-78

Fossen H (2010) Structural geology. Cambridge University Press, New York

Foster DA, Raza A (2002) Low temperature thermocronological record of exhumation of the Bitterrot metamorphic core complex, northern Cordilleran Orogen. Tectonophysics 349:23-36

Gans P, Mahood GA, Schermer E (1989) Synextensional magmatism in the Basin and Range Province: a case study from the eastern Great Basin. Geol Soc Am Spec Pap 233:1-53

Gifkins RC (1976) Grain boundary sliding and its accommodation during creep and superplasticity. Metall Mater Trans A 7A:1225-1232

Haas J, Cs Péró (2004) Mesozoic evolution of the Tisza Mega-unit. Int J Earth Sci 93(2):297-313

Haas J, Budai T, Csontos L, Fodor L, Konrád G (2010) Pre-Cenozoic geological map of Hungary, 1:500,000. Geological Institute of Hungary, Budapest

Haertel M, Herwegh M, Pettke T (2013) Titanium-in-quartz thermometry on synkinematic quartz veins in a retrograde crustal-scale normal fault zone. Tectonophysics 608:468-481

Halfpenny A, Prior DJ, Wheeler J (2012) Electron backscatter diffraction analysis to determine the mechanisms that operated during dynamic recrystallisation of quartz-rich rocks. J Struct Geol 36:2-15

Heidrick TL, Wilkins JW (1980) Field guide to the geology and ore deposits of the Buckskin Mountains. Arizona Geological Society, Spring Field Trip Guide, Arizona, p 31045

Hills ES (1956) A contribution to the morphotectonics of Australia. J Geol Soc Aust 3:1-15

Hirth G, Tullis J (1992) Dislocation creep regimes in quartz aggregates. J Struct Geol 14:145-159 
Holdsworth RE, Butler CA, Roberts AM (1997) The recognition of reactivation during continental deformation. J Geol Soc Lond 154:73-78

Holdsworth RE, Hand M, Miller JA, Buick IS (2001) Continental reactivation and reworking: an introduction. In: Miller JA, Holdsworth RE, Buick IS, Hand M (eds) Continental reactivation and reworking, vol 184. Geological Society, London, Special Publications, Bath, pp 1-12

Horváth H, Cloetingh S (1996) Stress-induced late-stage subsidence anomalies in the Pannonian Basin. Tectonophysics 266:287-300

Horváth F, Dövényi P, Szalay Á, Royden LH (1988) Subsidence, thermal, and maturation history of the Great Hungarian Plain. Am Assoc Pet Geol Mem 45:355-372

Huang R, Audétat A (2012) The titanium-in-quartz (TitaniQ) thermobarometer: a critical examination and re-calibration. Geochim Cosmochim Acta 84:75-89

Kerrich R (1988) Detachment zones of Cordilleran metamorphic core complexes: thermal, fluid and metasomatic regimes. Geol Rundsch 77(1):157-182

Kidder S, Avouac J-P, Chand Y-C (2013) Application of titanium-in-quartz thermobarometry to greenschistfacies veins and recrystallized quartzites in the Hsüehshan range, Taiwan. Solid Earth 4:1-21

Konrád Gy, Sebe K, Halász A, Babinszki E (2010) Sedimentology of Permian playa lake: the Boda Claystone Formation, Hungary. Geologos 16(1):27-41

Lelkes-Felvári G, Frank W (2006) Geochronology of the metamorphic basement, transdanubian part of the tisza mega-unit. Acta Geol Hung 49(3):189-206

Lister GS, Davis GA (1989) The origin of metamorphic core complexes and detachment faults formed during Tertiary continental extension in the northern Colorado River region. USA J Struct Geol 11(1/ 2):65-94

Lister GS, Etheridge MA, Symonds PA (1986) Application of the detachment fault model to the formation of passive continental margins. Geology 14:246-250

Lloyd GE, Law RD, Mainprice D, Wheeler J (1992) Microstructural and crystal fabric evolution during shear zone formation. J Struct Geol 14:1079-1100

Menegon L, Pennacchioni G, Heilbronner R, Pittarello L (2008) Evolution of quartz microstructure and c-axis crystallographic preferred orientation within ductilely deformed granitoids (Arolla unit, Western Alps). J Struct Geol 30:1332-1347

Michon L, Van Balen RT, Merle O, Pagnier H (2003) The Cenozoic evolution of the Roer Valley rift system integrated at a European scale. Tectonophysics 367:101-126

Molnár L, M Tóth T, Schubert F (2014a) Structural controls on the petroleum migration and entrapment within faulted basement blocks of Szeghalom Dome (Pannonian Basin, SE Hungary). In press, Geol Croat

Molnár L, Vásárhelyi B, M Tóth T, Schubert F (2014b) Integrated petrographic_rock mechanic borecore study from the metamorphic basement of the Pannonian Basin, Hungary. Open Geosci 7(1):53-64

Nagy Á, M Tóth T (2012) Petrology and tectonic evolution of the Kiskunhalas-NE fractured hydrocarbon reservoir, South Hungary. Cent Eur Geol 55(1):1-22

Olsen KH, Baldridge WS, Callender JF (1987) Rio Grande rift: an overview. Tectonophysics 143:119-139

Passchier CW, Trouw RAJ (2005) Microtectonics. Springer, Berlin

Piper JDA, Dagley P, Carpenter AH (2010) Detachment and rotation of a metamorph core complex during extensional deformation: palaeomagnetic study of the Catalina-Rincon Core Complex, Basin and Range Province, Arizona. Tectonophysics 488:191-209

Posgay K, Takács E, Szalay I, Bodoky T, Hegedűs E, Kántor JI, Timár Z, Varga G, Bérczi I, Szalay Á, Nagy Z, Pápa A, Hajnal Z, Reilkoff B, Mueller S, Ansorge J, De Iaco R, Asudeh I (1996) International deep reflection survey along the Hungarian Geotraverse. Geophys Trans 40(1-2):1-44

Prucha JJ (1992) Zone of weakness concept: a review and evaluation. In: Bartholomew MJ, Hyndman DW, Mogk DW, Mason R (eds) Basement tectonics 8: characterization and comparison of ancient and Mesozoic continental margins. In: Proceedings of the Eighth International Conference on Basement Tectonics held in Butte, Montana, USA, August 1988. Kluwer Academic Publishers, New York, pp 83-92

Rider M (1996) The geological interpretation of well logs, 2nd edn. Whittles, Caithness

Rutter EH, Holdsworth RE, Knipe RJ (2001) The nature and tectonic significance of fault-zone weakening: an introduction. In: Holdsworth RE, Strachan RA, Magloughlin JF, Knipe RJ (eds) The nature and tectonic significance of fault zone weakening, vol 186. Geological Society of London, Special Publication, Bath, pp 1-11

Schlumberger Limited (1989) Log interpretation principles/applications. Schlumberger Wireline \& Testing, Texas

Schubert F, M Tóth T (2001) Structural evolution of mylonitized gneiss zone from the Norther flank of the Szeghalom dome (Pannonian Basin, SE, Hungary). Acta Mineral Petrogr Szeged 42:59-64 
Shigematsu N (1999) Dynamic recrystallization in deformed plagioclase during progressive shear deformation. Tectonophysics 305:437-452

Skultéti Á, M Tóth T, Fintor K, Schubert F (2014) Deformation history reconstruction using single quartz grain Raman microspectroscopy data. J Raman Spectrosc 45(4):314-321

Sonder L, England PC (1986) Vertical averages of rheology of the continental lithospheric: relation to thin sheet parameters. Earth Planet Sci Lett 7:81-90

Stipp M, Stünitz H, Heilbronner R, Schmid SM (2002) The eastern Tonale fault zone: a'natural laboratory' for crystal plastic deformation of quartz over a temperature range from 250 to 700 \& \#xB0;C. J Struct Geol 24:1861-1884

Stockli DF, Brichau S, Dewane TJ, Hager C, Schroeder J (2006) Dynamics of large-magnitude extension in the Whipple Mountains metamorphic core complex. Goldschmidt Conference Abstracts A616

Szederkényi T (1977) Geological evolution of South Transdanubia (Hungary) in Paleozoic time. Acta Min Pet Szeged 23(1):3-14

Szederkényi T (1979) Origin of amphibolites and metavolcanics of crystalline complexes of south Transdanubia, Hungary. Acta Geol Hung 26(1-2):103-136

Szederkényi T (1984) Az Alföld kristályos aljzata és földtani kapcsolatai. DSc thesis, pp 183

Szederkényi T (1996) Metamorphic formations and their correlation in the Hungarian part of the Tisza Megaunit (Tisza Composite Terrane). Acta Min Pet Szeged 37:143-160

Tari G, Horváth F, Rumpler J (1992) Styles of extension in the Pannonian Basin. Tectonophysics 208(1-3):203-219

Tari G, Dövényi P, Dunkl I, Horváth F, Lenkey L, Stefanescu M, Szafián P, Tóth T (1999) Lithospheric structure of the Pannonian basin derived from seismic, gravity and geothermal data. Geol Soc Lond Spec Publ 156:215-250

Thomas JB, Watson EB, Spear FS, Shemella PT, Nayak SK, Lanzirozzi A (2010) TitaniQ under pressure: the effect of pressure and temperature on the solubility of $\mathrm{Ti}$ in quartz. Contrib Mineral Petrol 160:743-759

Thorbergsdottir IM, Tulinius H, Ádám L, Gudmundsson G, Halldórsdottir HB, Traustason S, Hu Z, Yu G (2010) Geothermal Drilling for Space Heating in the Town of Szentlörinc in SW Hungary. Proceedings World Geothermal Congress, Bali, pp 1-5

Tittman J, Wahl JS (1965) The physical foundations of formation density logging (gamma-gamma). Geophysics 31(2):284-294

M Tóth T (2014) Geochemistry of the Görcsöny Ridge amphibolites (Tisza Unit, SW Hungary) and its geodynamic consequences. Geol Croat 67(1):17-32

M Tóth T, Zachar J (2006) Petrology and deformation history of the metamorphic basement in the MezősasFurta crystalline high (SE Hungary). Acta Geol Hung 49(2):165-188

M Tóth T, Schubert F, Zachar J (2000) Neogene exhumation of the Variscan Szeghalom Dome, Pannonian Basin, E. Hungary. Geol J 35:265-284

Tulinius H, Thorbergsdottir IM, Ádám L, Hu Z, Yu G (2010) Geothermal Evaluation in Hungary using integrated interpretation of well, seismic and MT Data. Proceedings World Geothermal Congress, Bali, pp 1-7

Tullis J, Stünitz H, Teysser C, Heilbronner R (2000) Deformation microstructures in quartzo-feldspathic rocks. In: Jessel MW, Urai JL (eds): Stress, strain and structure. A volume in honour of WD means. J Virtual Explor 2

Vernon RH (2004) A practical guide to rock microstructure. Cambridge University Press, Cambridge

Wark DA, Watson EB (2006) TitaniQ: a titanium-in-quartz geothermometer. Contrib Mineral Petrol 152:743-754

Wernicke B (1985) Uniform-sense normal simple shear of the continental lithosphere. Can J Earth Sci 22: $108-125$

Wernicke B, Burchfiel BC (1982) Modes of extensional tectonics. J Struct Geol 4:105-115

White SH (1976) The role of dislocation processes during tectonic deformation with special reference to quartz. In: Strens RJ (ed) The physics and chemistry of minerals and rocks. Wiley, London, pp 75-91

White SH, Bretan PG, Rutter EH (1986) Fault-zone reactivation: kinematics and mechanisms. Philos Trans R Soc Lond A317:81-97

Wibberley CAJ, Yielding G, Di Toro G (2008) Recent advances in the understanding of fault zone internal structure: a review. In: Wibberley CAJ, Kurz W, Imber J, Holdsworth RE, Collettini C (eds) The internal structure of fault zones: implications for mechanical and fluid-flow properties. Special Publication 299, London: Geological Society, pp. 5-33

Wilson JT (1966) Did the Atlantic close and then reopen? Nature 211:676-681

Zachar J, M Tóth T (2004) Petrology of metamorphic basement of the Tisza Block at the Jánoshalma High, S Hungary. Acta Geol Hung 47(4):349-371 